\title{
A CONTRIBUTION TO THE TERMINOLOGY OF ICHTHYOGRAPHY.
}

\section{By THEODORE GILL.}

A desideratum of ichthyography, or descriptive ichthyology, has been a system of terminology by which the forms characteristic of rarious types of fishes could be tersely and aptly expressed. In common with others, I have hitherto employed phraseology expressive of likeness to certain specific forms, such as Perciform, Spariform, Scombriform, Cottiform, Gadiform, \&c. But such terms are often taken too literally, or, when explained away, lose almost all significance. When the constituents of natural families are compared, however, as Professor Agassiz long ago suggested, * there is generally (not always) found to be a certain similarity which on analysis often proves to be the result of the extension of the body in a definite direction. This tendency can be expressed by terms derived in the same way as many generally accepted ones (e. g., dorsad, caudad, ventrad, \&c.) with the suffix form. Some others can be used with current meanings. The advantage of such a course will be (1) to direct immediate attention to the principal element of the form, (2) to dissever the general idea from a special one, and (3) to insure conciseness and absence, or at least a minimum, of periphrasis in description. I shall now give only some illustrations :

\section{I.}

The form most eminently adapted for direct horizontal progression in the water is that exemplified in the Tunny and its relations, Trachurus, Gasterosteus, \&c. It is the fusiform contonr.

In most fishes there is, however, a greater or less deviation from this form to enable the fish more readily to descend or ascend or otherwise accommodate itself to its most advantageus movements.

\section{II.}

In most forms extension takes place in an upward direction. In the Perches and many others the tendency of extension is upwards above the shoulders or in the region of the front of the back. This may be called dorsadiform.

* The idea of taking form as a family characteristic in ichthyology originated with de Blainville in 1816. In the "Squammodermes" or scaly fishes, he defined the families by their form. Metrosomes, "de forme ordinaire"; Subencheliosomes, "longue et subcylindrique;" Encheliosomes, "lougue et cylindrique," \&c. Some of these are repeated under several orders, e. g. : Subencheliosomes under the Tetrapodes Abdom. inaux (Cobites), T. Thoraciques (Gobies, Callionymes), T. Jugulaires, and Dipodes (Gymnotes). How little of precision was connected with de Blainville's idea may be inferred from the fact that under Metrosomes he embraced Esox, Clupea, Salmo, Cyprinus (Ahdominaux), Labrus (Thoraciques), and Gadus (Jugulaires). 
In the Equulids, among others, the extension is in the region just behind the cranium or about the nape, and hence such may be called nuchadiform.

In the Patæcids the extension is to the direction of the front of the head, and a frontadiform outline results.

III.

In certain other types it is the inferior region that is expanded.

In the Sternoptychids the extension is downwards in front of the anal region; the resulting shape is the ventradiform.

In the Zenids and Gerrids the tendency of expansion is about the thoracic region; it may (taking advantage of a frequently used analogy) be designated the sternadiform.

\section{IV.}

Certain other forms do not manifest any decided deviation one way or another in a vertical direction.

The Centrarchids, Cichlids, Labrids, Pimelepterids (or Cyphosids, if it is deemed best), and many others have the dorsal and inferior outlines almost exactly inverted, so that, if the body (exclusive of head) could be simply folded lengthwise, the two margins would be found to be nearly coincident. The shape thus constituted may be designated antadiform.

In the Chætodontids, an apparent expansion is manifested by the encroachment of the skin and scales on the soft dorsal and anal fins, and they may be distinguished as pinnadiform.

In many fishes, such as the Coryphænids, Uranoscopids, Batrachids, Triglids, \&c., the body regularly incr eases in height or vertical extension towards the head, and they are consequently antrorsiform.

In Lampris, the height is greatest considerably in advance of the middle, and hence an oviform outline ensues.

In the Trichiurids and some others the body is much elongated and greatly compressed, and they have quite generally and appropriately been called taniiform or ribbon-shaped.

$$
\text { V. }
$$

Some exceptional deviations are manifested by rery different forms.

The Toxotids and Amphisilids are both distinguished by a sort of depression or flattening of the dorsal outline from the head backwards to the dorsal fin. The name retradiform may be used to express this feature.

\section{VI.}

Other names, derived from special types, may be used inasmuch as they already have some currency and are not apt to produce much misconception. Such are anguilliform, platessiform, soleiform, squaliform, \&c. 


\section{$2 \mathrm{BHL}$ Biodiversity Heritage Library}

Gill, Theodore. 1884. "A contribution to the terminology of ichthyography." Proceedings of the United States National Museum 7(445), 356-357. https://doi.org/10.5479/si.00963801.7-445.356.

View This Item Online: https://www.biodiversitylibrary.org/item/31798

DOI: https://doi.org/10.5479/si.00963801.7-445.356

Permalink: https://www.biodiversitylibrary.org/partpdf/11576

\section{Holding Institution}

Smithsonian Libraries

\section{Sponsored by}

Smithsonian

\section{Copyright \& Reuse}

Copyright Status: NOT_IN_COPYRIGHT

This document was created from content at the Biodiversity Heritage Library, the world's largest open access digital library for biodiversity literature and archives. Visit BHL at https://www.biodiversitylibrary.org. 